\title{
Nomenclatural Changes in Western North American Amsinckiinae (Boraginaceae)
}

\author{
C. Matt Guilliams* and Kristen E. Hasenstab-Lehman
}

Department of Conservation and Research, Santa Barbara Botanic Garden, 1200 Mission Canyon Drive, Santa Barbara, California 93105, U.S.A.

\section{Bruce G. Baldwin}

Jepson Herbarium and Department of Integrative Biology, University of California, Berkeley, Berkeley, California 94720-2465, U.S.A.

*Author for correspondence: mguilliams@sbbg.org

ABSTRACT. Three recent phylogenetic studies have used DNA sequence data to examine evolutionary relationships in Amsinckiinae (Boraginaceae). In each of these studies, the genus Plagiobothrys Fisch. \& C. A. Mey. has been recovered as non-monophyletic. So that only monophyletic groups are recognized, two new genus names are provided here: Amsinckiopsis (I. M. Johnst.) Guilliams, Hasenstab \& B. G. Baldwin and Simpsonanthus Guilliams, Hasenstab \& B. G. Baldwin. The new combination P. collinus (Phil.) I. M. Johnst. var. pringlei (Greene) Guilliams \& B. G. Baldwin is given for plants from Arizona that were found to be phylogenetically nested within $P$. collinus. The genus name Sonnea Greene is lectotypified.

Key words: Amsinckia, Amsinckiinae, Amsinckiopsis, Boraginaceae, Plagiobothrys, Simpsonanthus, Sonnea.

The genus Plagiobothrys Fisch. \& C. A. Mey. (Boraginaceae) has been the subject of three recent molecular phylogenetic studies (Hasenstab-Lehman \& Simpson, 2012; Guilliams, 2015; Simpson et al., 2017). These efforts to elucidate phylogenetic relationships using DNA sequence data have revealed the non-monophyly of Plagiobothrys. Although the majority of minimum-rank taxa (species, subspecies, and varieties) in the genus form a clade that will retain the name Plagiobothrys, five have been found to be more closely related to other genera in subtribe Amsinckiinae. Plagiobothrys jonesii A. Gray and both varieties of $P$. kingii (S. Watson) A. Gray comprise Plagiobothrys sect. Amsinckiopsis I. M. Johnst. They have been found to be more closely related to the genus Amsinckia Lehm. than to the above-mentioned clade representing Plagiobothrys s. str. Plagiobothrys glomeratus A. Gray and P. hispidus A. Gray, corresponding to Plagiobothrys sect. Sonnea (Greene) I. M. Johnst., form another clade that is recovered in various positions in the broader Amsinckiinae tree. These phylogenetic patterns are discussed in detail in the next section.
With two current floristic treatments on the genus underway (Guilliams et al., 2020; Guilliams et al., in prep.), a nomenclatural solution to the non-monophyly of Plagiobothrys is required. So that only monophyletic groups are recognized taxonomically, presented here are two new genus names and associated new combinations for taxa therein, the lectotypification of the existing genus name Sonnea Greene to which taxa of Plagiobothrys sect. Sonnea are better referred, and a new combination within Plagiobothrys.

\section{Summary of Recent Phylogenetic Analyses}

Hasenstab-Lehman and Simpson (2012) performed the first well-sampled phylogenetic study focusing on Amsinckiinae using DNA sequence data from the internal transcribed spacer (ITS) region of the 18S-26S nuclear ribosomal cistron (nrDNA) and the non-coding trnL-trnF spacer of the chloroplast genome (cpDNA). The study included 64 samples of 60 taxa of Amsinckiinae from nearly all recognized genera. Phylogenetic analyses were performed using parsimony, maximum likelihood, and Bayesian approaches, with one goal being to assess the correspondence between evolutionary history and current generic circumscriptions. In the parsimony analysis, the four samples included of Amsinckia were recovered as a monophyletic group with strong support (100 bootstrap support value [BS]), with this clade of Amsinckia sister to one sample of Plagiobothrys kingii var. kingii with no support (< $70 \mathrm{BS})$. Plagiobothrys jonesii was recovered as sister to a clade of Greeneocharis Gürke \& Harms-Plagiobothrys s. str., but with no support $(<70 \mathrm{BS})$. In the maximum likelihood and Bayesian analyses, $P$. kingii var. kingii and P. jonesii formed a clade with no support $(<70 \mathrm{BS}$, posterior probability $[\mathrm{PP}]$ not reported), sister to a strongly supported clade of Amsinckia (100 BS/1 PP). This pattern is summarized in Figure 1A. Plagiobothrys hispidus was recovered as sister to a clade of Eremocarya 

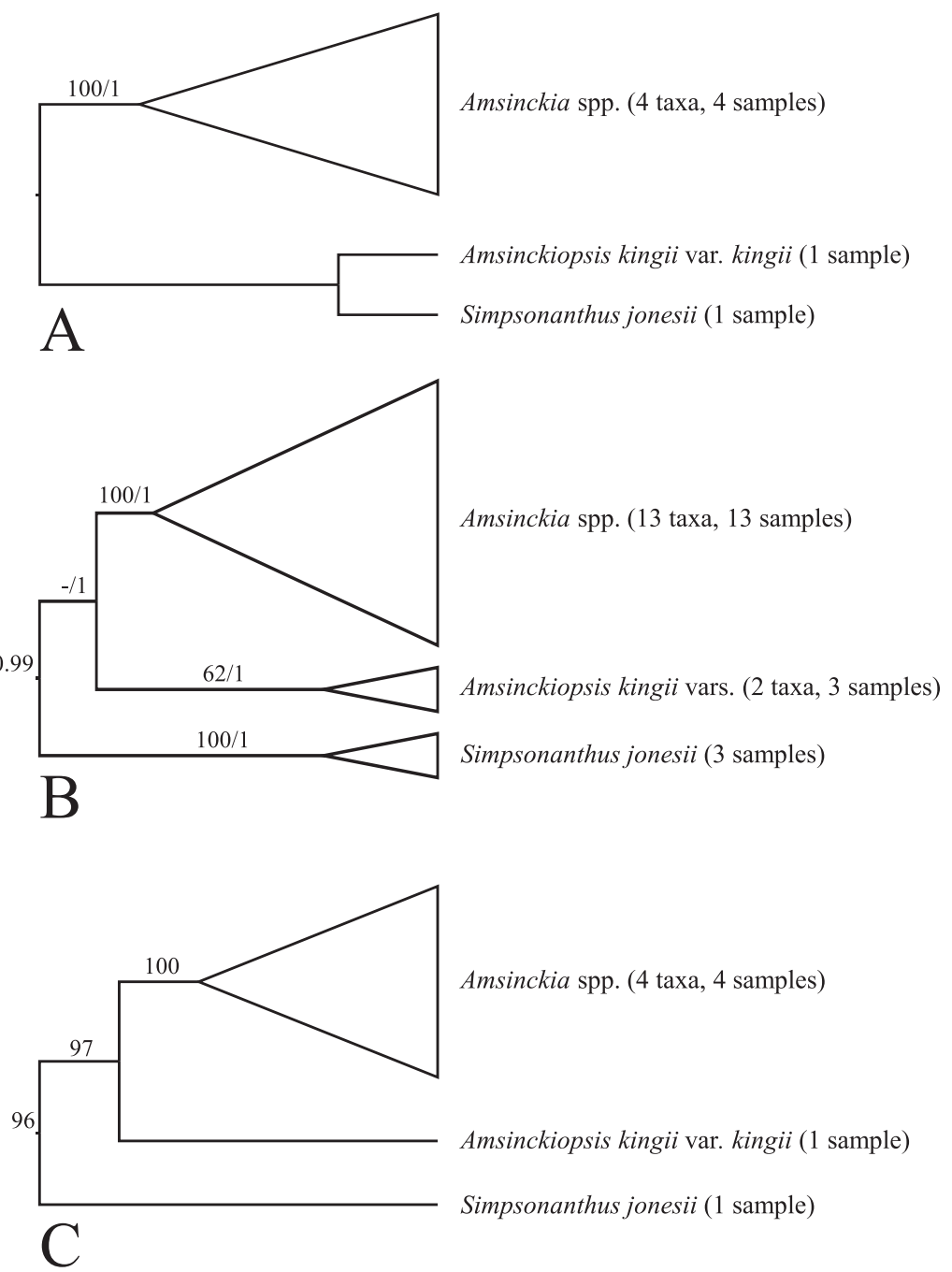

Figure 1. A-C. Simplified diagrams showing evolutionary relationships inferred in three previous molecular phylogenetic studies of Amsinckiinae. - A. Tree diagram from Hasenstab-Lehman and Simpson (2012): maximum likelihood analysis of concatenated nrDNA + cpDNA; values on branches are maximum likelihood bootstrap proportions and Bayesian posterior probabilities (PP). - B. Tree diagram from Guilliams (2015): maximum likelihood analysis of concatenated nrDNA + cpDNA; values on branches are maximum likelihood bootstrap proportions and Bayesian PP. - C. Tree diagram from Simpson et al. (2017): maximum likelihood analyses; values on branches are maximum likelihood bootstrap proportions from separate cpDNA, mtDNA, and concatenated analyses (latter not shown).

Greene-Oreocarya Greene in the parsimony, maximum likelihood, and Bayesian analyses, although statistical support for this relationship was only strong in the Bayesian analysis (0.97 PP).

Guilliams (2015), in a dissertation focusing on the systematics of the genus Plagiobothrys, used DNA sequence data from nrDNA (ITS and the external transcribed spacer [ETS] regions) and six regions of cpDNA (psbJ-petA intergenic spacer, rpl16 intron, rps16 intron, 3'trnK intron, 3'rps16-5'trnK intergenic spacer, trnLtrnF spacer) to infer relationships within Amsinckiinae.
The nrDNA dataset included 179 samples of 120 taxa of Amsinckiinae, while the cpDNA dataset was reduced to 143 samples due to lack of sequence variation in one taxonomically diverse clade of Plagiobothrys s. str. (section Allocarya I. M. Johnst., not discussed further here). Three samples each of $P$. jonesii and $P$. kingii were included along with 13 samples of Amsinckia, representing nearly all recognized taxa in the latter genus. Three samples each of $P$. glomeratus and $P$. hispidus were also included. Maximum likelihood and Bayesian phylogenetic analyses were performed on each 
dataset separately and then on a combined nrDNA + cpDNA matrix. Amsinckia, $P$. jonesii, and $P$. kingii were each reciprocally monophyletic with moderate to strong support in all analyses (Fig. 1B; Amsinckia and P. jonesii both 100 BS/1 PP, P. kingii 62 BS/1 PP). Although support for relationships among these taxa in the combined-data analysis was lacking in the maximum likelihood analysis, the Bayesian analysis recovered Amsinckia sister to $P$. kingii with strong support (1 $\mathrm{PP})$, and this clade sister to $P$. jonesii with strong support (0.99 PP). Samples of $P$. glomeratus and P. hispidus, the two members of Plagiobothrys sect. Sonnea, formed a clade with strong support in all analyses (100 BS/1 PP). This clade was sister to a morphologically diverse clade comprising the genera Pectocarya DC. ex Meisn., Harpagonella A. Gray, Dasynotus I. M. Johnst., Oreocarya, and Eremocarya. This grouping had strongest statistical support in the Bayesian analysis (0.93 PP).

Simpson et al. (2017) used the high-throughput sequencing technique, genome skimming, to generate data to evaluate relationships among 139 samples of Amsinckiinae, including representative samples from all major groupings (e.g., sections) of all genera of the subtribe. This sequencing technique resulted in the recovery of three large sequence datasets for each sample: a nearly complete cpDNA, a nearly complete nrDNA consensus, and 50 mitochondrial loci (mtDNA). Maximum likelihood and Bayesian phylogenetic analyses were performed for each dataset. In both analyses of each genomic dataset, the pattern found by Guilliams (2015) was confirmed: Plagiobothrys jonesii, P. kingii var. harknessii (Greene) Jeps., and P. kingii var. kingii formed a clade with Amsinckia, usually with strong support ( $\geq 70 \mathrm{BS}, \geq 0.95 \mathrm{PP}$ ). In this clade, Amsinckia was strongly supported as monophyletic, with the Amsinckia clade sister to the one included sample of $P$. kingii. The clade of Amsinckia-P. kingii was sister to the one included sample of $P$. jonesii. This pattern is depicted in Figure 1C. Section Sonnea taxa P. glomeratus and $P$. hispidus were recovered as a clade with strong support in all analyses, but placement varied in all analyses. In the cpDNA analysis, section Sonnea was sister to a monophyletic Plagiobothrys s. str. In the nrDNA analysis, the lineage giving rise to section Sonnea emerged from a deep phylogenetic split in the subtribe, sister to a diverse clade comprising most other genera sampled. In the mtDNA analysis, section Sonnea was sister to Greeneocharis.

In summary, all three previous phylogenetic analyses that have focused on Amsinckiinae have recovered $P$. jonesii and $P$. kingii as more closely related to Amsinckia than to Plagiobothrys s. str. Amsinckia was recovered as monophyletic with strong support in each of these previous studies. Where multiple exemplars of $P$. jonesii and P. kingii have been included (Guilliams, 2015), these taxa too have been recovered as monophyletic with strong support. The pattern of $P$. kingii as sister to Amsinckia was recovered for the first time in HasenstabLehman and Simpson (2012), and corroborated in both subsequent studies. Placement of $P$. jonesii as sister to Amsinckia-P. kingii was found by Guilliams (2015) in a study with expanded sampling and a larger sequence dataset, and then again by Simpson et al. (2017) with genomic data. Section Sonnea, including P. glomeratus and $P$. hispidus, was recovered as monophyletic with strong support in all analyses where more than one sample from the section was included (Guilliams, 2015; Simpson et al., 2017). However, section Sonnea has been variously placed in the Amsinckiinae outside of Plagiobothrys s. str., usually without strong statistical support.

\section{Morphological Synapomorphies}

Morphological synapomorphies support the Amsinckia clade, the Amsinckia-Plagiobothrys kingii-P. jonesii clade, and the section Sonnea clade. Morphological synapomorphies for the former two clades are shown along with a summary tree diagram in Figure 2. The genus Amsinckia, strongly supported in each of the molecular phylogenetic analyses, is united by two morphological synapomorphies: orange to yellow-orange corollas and bifid cotyledons. Within Amsinckiinae, orange to yellow-orange corollas are unique to Amsinckia (although yellow corollas separately evolved in two species of the genus Oreocarya) and serve as an excellent diagnostic character for the genus, especially in the field. Also in the subtribe, bifid cotyledons are found only in Amsinckia (all taxa) and in a few species of South American Cryptantha Lehm. ex G. Don, section Geocarya I. M. Johnst. (Grau, 1983), in which they evolved independently. The clade of Amsinckia-P. kingii-P. jonesii is united in having an elongate attachment scar that is positioned along the adaxial or "ventral" keel of the nutlet, and a hirsute to hispid vestiture throughout. Both of these features were previously described by Johnston (1923: 58-59), who stated of $P$. jonesii and $P$. kingii:

These species differ from those in genuine Plagiobothrys by having a coarse hispid pubescence and nutlet which superficially closely simulate the nutlets of Amsinckia. ... The nutlets have a submedial scar that is borne, not at or below the lower end of the ventral keel, but surrounded by and wedged in between the pericarpial margins that form the keel and consequently appearing at first glance to be borne upon it. The striking nutlet difference seems of funamental [sic] importance and were other important concomitant characters forthcoming I should feel that the group merits generic recognition.

The position of the attachment scar well above the middle of the adaxial or "ventral" surface of the nutlet 


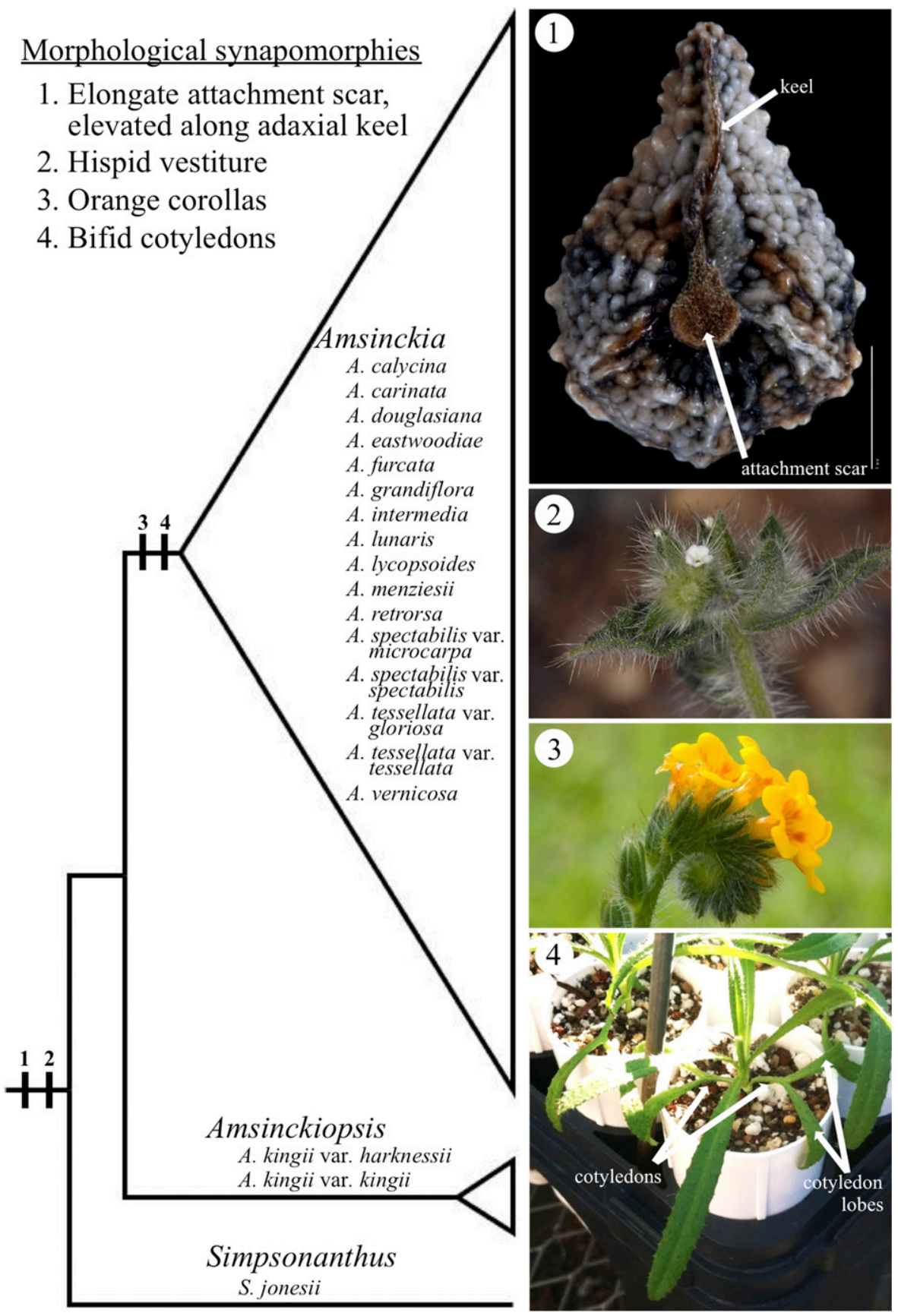

Figure 2. Morphological synapomorphies of the clade consisting of Simpsonanthus Guilliams, Hasenstab \& B. G. Baldwin-(Amsinckiopsis (I. M. Johnst.) Guilliams, Hasenstab \& B. G. Baldwin-Amsinckia Lehm.). Characters 1 and 2-elongate attachment scar, elevated along the adaxial keel and hispid vestiture — evolved in the lineage leading to the common ancestor of the Simpsonanthus-(Amsinckiopsis-Amsinckia) clade. Characters 3 and 4-orange corollas and bifid cotyledons-evolved in the lineage leading to the common ancestor of Amsinckia. Photograph 1 by Michael Simpson, photograph 2 by Steve Matson, photograph 3 by Barry Rice, photograph 4 by C. Matt Guilliams. 

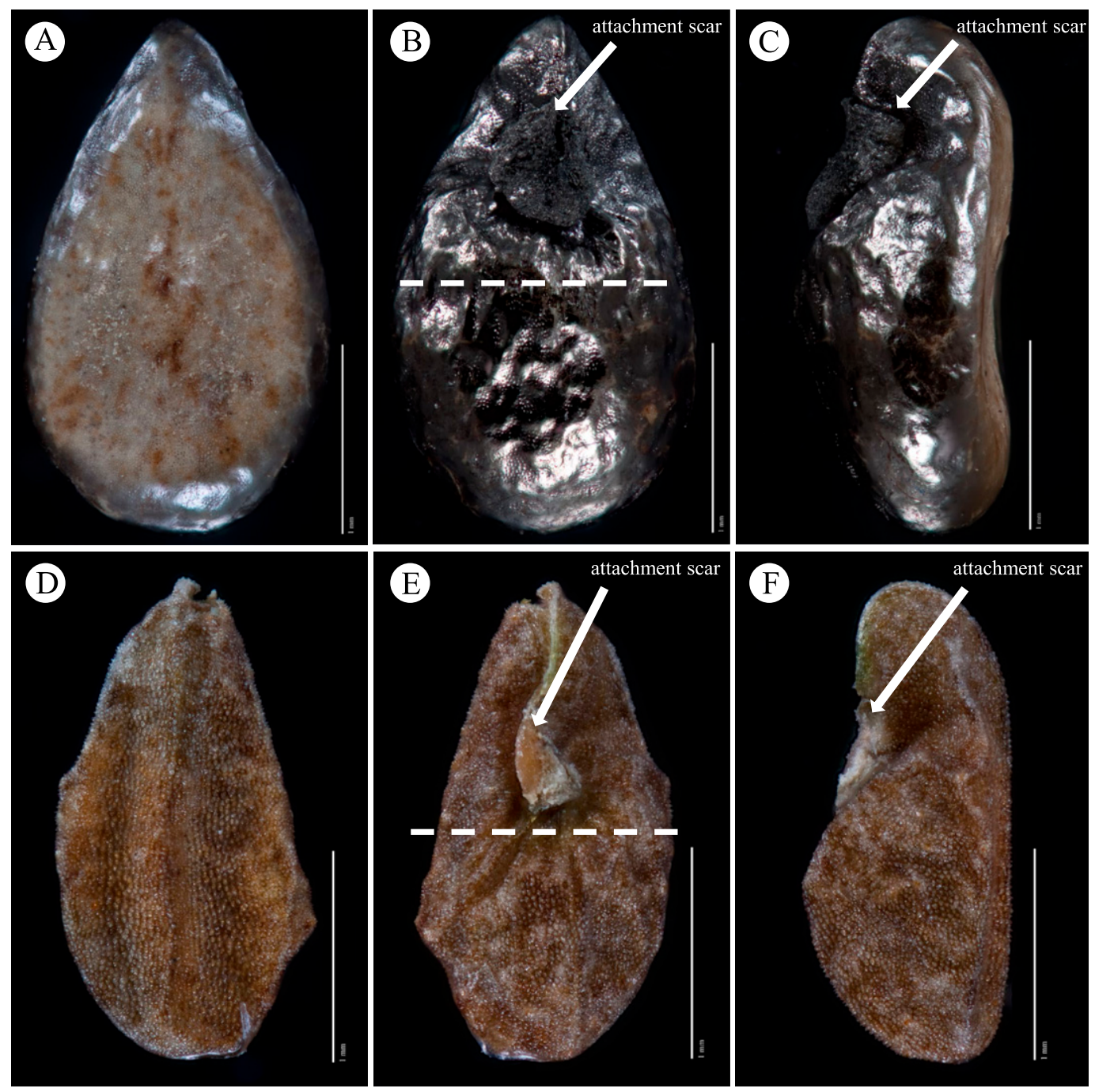

Figure 3. Morphological synapomorphy of the Sonnea Greene clade: an attachment scar positioned above the middle on the adaxial surface of the nutlet. A-C. Nutlets of S. glomerata (A. Gray) Greene (Curran s.n., 1884). —A. Abaxial view. -B. Adaxial view; dashed line at approximate middle of nutlet. - C. Lateral view. D-F. Nutlets of S. hispida (A. Gray) Greene (Taylor 16824). -D. Abaxial view. - E. Adaxial view; dashed line at approximate middle of nutlet. —F. Lateral view. Photographs by Michael Simpson.

is a synapomorphy for the two species of the section Sonnea clade (Fig. 3). This type of attachment scar is found in no other species of the subtribe.

Finally, the analyses of Guilliams (2015) demonstrated that all samples of Plagiobothrys pringlei Greene were phylogenetically nested among samples representing the varieties of $P$. collinus (Phil.) I. M. Johnst. All of these taxa possess an elongate stalklike structure bearing the attachment scar, unique in the genus and the subtribe.

Nomenclatural changes are necessary to recognize monophyletic groups in the Amsinckiinae, given the phylogenetic patterns described above. Two new names at genus rank are described here for Plagiobothrys jonesii and $P$. kingii, along with new combinations for infraspecific taxa in each. These two new genera are readily distinguished from others in Amsinckiinae and their recognition allows Amsinckia to be retained in its traditional sense, which is much more readily diagnosable without expansion of the genus to include $P$. jonesii and $P$. kingii. Given the monophyly of section Sonnea and the varying phylogenetic placement of the section Sonnea clade outside of Plagiobothrys, the older genus name Sonnea (lectotypified here) should be used for 
P. glomeratus and P. hispidus. Lastly, the discovery by Guilliams (2015) that $P$. pringlei is nested within a deeper clade of the different varieties of $P$. collinus would render the latter species paraphyletic as currently circumscribed. A new varietal combination is therefore made for $P$. pringlei within $P$. collinus.

\section{Taxonomic Treatment}

Amsinckiopsis (I. M. Johnst.) Guilliams, Hasenstab \& B. G. Baldwin, stat. nov. Basionym: Plagiobothrys sect. Amsinckiopsis I. M. Johnst., Contr. Gray Herb. 68: 59. 1923. TYPE: Eritrichium kingii S. Watson [三 Amsinckiopsis kingii (Watson) Guilliams, Hasenstab \& B. G. Baldwin].

Annuals, 1-4 dm tall, hirsute and villous, taprooted. Stems ascending to erect, 1 to several. Leaves alternate, basal and cauline, simple, sessile, basal blades oblanceolate, cauline blades linear to lanceolate, $2-6 \mathrm{~cm}$, surfaces hirsute to hispid. Inflorescences circinate, scorpioid cymes, glomerate, not much elongating in fruit, bracteate near base, proximal bracts sometimes exceeding flowers; pedicels 0-2 mm. Calyces 5-6 mm, lobes lanceolate; corolla limbs 4-7 mm diam., white, fornices prominent, usually yellow, fading to white. Fruits schizocarps, mericarps (nutlets) usually 4; nutlets \pm ovate in outline, $2.5-3 \mathrm{~mm}$, abaxial surface sometimes with medial and lateral keels, irregularly rugose and papillate; attachment scar on adaxial surface, medial and positioned along raised adaxial keel, elongate, narrowly triangular to narrowly lanceolate, length ca. 1/2 that of the nutlet, scar apices acute.

Distribution, habitat and phenology. Amsinckiopsis is known from southeastern Oregon and eastern California to western Utah; it is most common in Nevada. Taxa usually occur on sandy and gravelly substrates, less commonly on volcanic and clay substrates, in valleys and on bajadas from approximately 1200 to $2100 \mathrm{~m}$ (4000 to $7000 \mathrm{ft}$.) in open vegetation types. Flowering occurs from April to June (July).

Notes. Amsinckiopsis is distinctive in Amsinckiinae in having the combination of hirsute to hispid vestiture throughout; more or less glomerate, circinate, scorpioid cymes; white corollas; and nutlets with rugose and papillate sculpturing and an elongate attachment scar positioned along a raised, adaxial keel. Amsinckiopsis differs from Simpsonanthus Guilliams, Hasenstab \& B. G. Baldwin in having more or less glomerate inflorescences, larger corolla limbs (4-7 mm vs. 1-3 mm), more prominent fornices, and nutlets with a rugose and papillate abaxial surface (vs. tessellate in Simpsonanthus; Fig. 4).

Amsinckiopsis kingii (S. Watson) Guilliams, Hasenstab \& B. G. Baldwin, comb. nov. Basionym: Eritrichium kingii S. Watson, Botany (Fortieth Parallel): 243, pl. 23, f. 3-5. 1871. Plagiobothrys kingii (S. Watson) A. Gray, Proc. Amer. Acad. Arts 20: 281. 1885. TYPE: U.S.A. California: "Eastern side of the Sierra Nevada at Truckee Pass," 1865, S. Watson 854 (holotype, GH image!).

Amsinckiopsis kingii var. harknessii (Greene) Guilliams, Hasenstab \& B. G. Baldwin, comb. nov. Basionym: Sonnea harknessii Greene, Pittonia 1(2): 23. 1887. Plagiobothrys harknessii (Greene) A. Nelson \& J. F. Macbr., Bot. Gaz. 62(2): 143. 1916. Plagiobothrys kingii (S. Watson) A. Gray var. harknessii (Greene) Jeps., Man. Fl. Pl. Calif.: 856. 1925. TYPE: U.S.A. California: "Mono Lake, Sierra Nevada," June 1886, H. W. Harkness s.n. (holotype, NDG image!).

Simpsonanthus Guilliams, Hasenstab \& B. G. Baldwin, gen. nov. TYPE: Plagiobothrys jonesii A. Gray [” Simpsonanthus jonesii (A. Gray) Guilliams, Hasenstab \& B. G. Baldwin].

Diagnosis. Simpsonanthus Guilliams, Hasenstab \& B. G. Baldwin is distinctive in Amsinckiinae in having the combination of hirsute to hispid vestiture throughout; non-glomerate, circinate, scorpioid cymes; white corollas; and nutlets with tessellate abaxial nutlet sculpturing and an elongate attachment scar positioned along a raised, adaxial keel. Simpsonanthus differs from Amsinckiopsis (I. M. Johnst.) Guilliams, Hasenstab \& B. G. Baldwin in having elongate inflorescences in fruit, smaller corolla limbs (1-3 $\mathrm{mm}$ vs. $4-7 \mathrm{~mm})$, minute fornices, and nutlets with a tessellate abaxial surface (vs. rugose and papillate in Amsinckiopsis; Fig. 4).

Annuals to $5 \mathrm{dm}$ tall, taprooted, usually few to several branched throughout. Stems ascending to erect, hirsute to hispid and with shorter, fine, spreading to retrorse hairs. Leaves alternate, cauline, simple, sessile, blades oblong to elliptic, distally sometimes lanceolate, $2-10 \mathrm{~cm}$, usually hispid with pustulate-based hairs, sometimes hirsute and/or with short, fine hairs. Inflorescences circinate, scorpioid cymes, elongate, proximally bracteate; pedicels 0-1 mm. Calyces 4-8 mm, hirsute, lobes narrowly lanceolate to \pm linear, margins often ciliate; corollas \pm funnel-shaped, white, limb 1-3 mm diam., fornices minute, light yellow, fading to white. Fruits schizocarps, mericarps (nutlets) 3 to 4 ; nutlets triangular-ovoid, 2-3 mm, abaxial surfaces tessellate, coarse tubercles absent, abaxial and lateral ridges \pm poorly defined to absent, transverse ridges and grooves absent, adaxial keel present; nutlet attachment scar medial on adaxial surface along crest of adaxial keel, narrowly lanceolate to narrowly triangular, irregular, length ca. 1/2 that of the nutlet.

Distribution, habitat, and phenology. Simpsonanthus is known in California predominantly east of the Sierra Nevada in the central part of the state and through the Mojave and Colorado deserts. It extends through the southern half of Nevada to southern Utah and through Arizona 

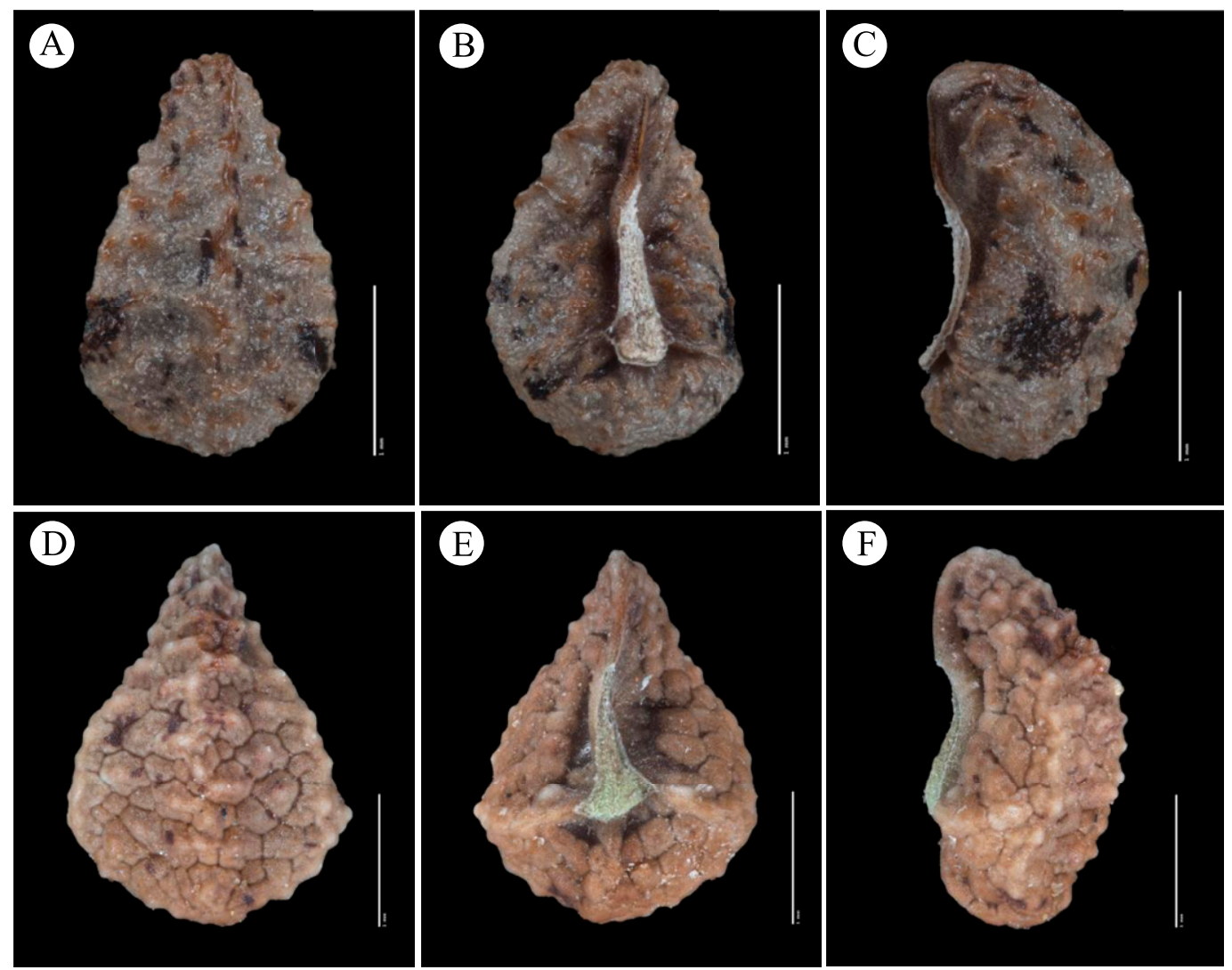

Figure 4. A-C. Nutlets of Amsinckiopsis kingii var. harknessii (Greene) Guilliams, Hasenstab \& B. G. Baldwin (Ahart 11891). —A. Abaxial view. - B. Adaxial view. - C. Lateral view. D-F. Nutlets of Simpsonanthus jonesii (A. Gray) Guilliams, Hasenstab \& B. G. Baldwin (Sanders 27585). —D. Abaxial view. - E. Adaxial view. - F. Lateral view. Photographs by Michael Simpson. Scale bars: each $1 \mathrm{~mm}$.

to Mexico, where it is known from northwestern Sonora and from Isla Angel de la Guarda at Refugio Bay in the Gulf of California. It occurs on sandy, gravelly, and rocky substrates in washes and on slopes from ca. 90 to $1770 \mathrm{~m}$ (30 to $5800 \mathrm{ft}$.) in desert vegetation including creosote bush scrub and pinyon-juniper woodland. Flowering typically occurs from March to May, sometimes in January, February, and June.

Etymology. Simpsonanthus is named after Michael G. Simpson, Professor Emeritus of Biology at San Diego State University, who has contributed greatly to the study of Amsinckiinae.

Simpsonanthus jonesii (A. Gray) Guilliams, Hasenstab \& B. G. Baldwin, comb. nov. Basionym: Plagiobothrys jonesii A. Gray, Syn. Fl. N. Amer. (ed. 2) 2(1): 430. 1886. TYPE: U.S.A. California: "Needles," 5 May 1884, M. E. Jones s.n. (holotype, GH image!).

Plagiobothrys collinus (Phil.) I. M. Johnst. var. pringlei (Greene) Guilliams \& B. G. Baldwin, comb. nov. Basionym: Plagiobothrys pringlei Greene, Pittonia
1(2): 21. 1887. TYPE: U.S.A. Arizona: "Verde Mesa, Arizona," s.d., Dr. Smart s.n. (holotype, GH image!).

Notes. Plagiobothrys pringlei was originally published under the name Echidiocarya arizonica A. Gray in 1876. Greene (1887) transferred it to Plagiobothrys as $P$. pringlei Greene, choosing a new specific epithet because "arizonicus" was already in use for $P$. arizonicus (A. Gray) Greene ex A. Gray. Absence of an available name at varietal rank for $P$. pringlei permits us to use either "arizonicus" or "pringlei" for the new varietal combination in P. collinus. Given the longstanding recognition of this taxon under the name $P$. pringlei, we use the epithet "pringlei" in our new combination.

\section{LectotyPification OF SONNEA}

When Greene named Sonnea in 1887, his circumscription included five minimum-rank taxa. Based upon the phylogenetic evidence discussed above, only $S$. glomerata (A. Gray) Greene and S. hispida (A. Gray) Greene are retained in Sonnea; the other three taxa, Plagiobothrys 
jonesii and the varieties of $P$. kingii, are more closely related to Amsinckia, as described above, and are treated in Simpsonanthus and Amsinckiopsis. Therefore, Sonnea hispida is selected here as an appropriate type.
Sonnea Greene, Pittonia 1(2): 22. 1887. TYPE (lectotype, designated here): Plagiobothrys hispidus A. Gray, Proc. Amer. Acad. Arts 20: 286. 1885 [三 Sonnea hispida (A. Gray) Greene].

Revised Key to Genera of the Amsinckinnae (Modified from Simpson, 2007 onward; Kelley et al., 2012; and Cohen, 2015)

1. Plants perennial; leaves relatively large, generally $>5 \mathrm{~cm}$ long; nutlets (3.5-)5-12 mm long.

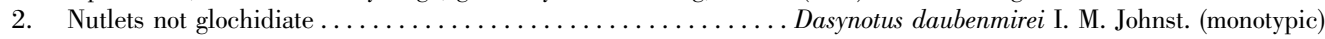

$2^{\prime}$. Nutlets glochidiate.

3. Corollas green to lemon-yellow to brown, inflorescences somewhat bracteate; plants of Mexico ........ $\ldots \ldots \ldots \ldots \ldots \ldots \ldots \ldots \ldots \ldots \ldots \ldots \ldots \ldots \ldots \ldots \ldots \ldots \ldots \ldots \ldots \ldots$ Oncaglossum pringlei (Greenm.) Sutorý (monotypic) 3'. Corollas white to blue to red to purple, inflorescences ebracteate; plants of the U.S.A. and Canada.

4. Cauline leaves petiolate, pedicels not recurved in fruit, stems glabrous . . . . . . . . . . . .............................. Adelinia grandis (Douglas ex Lehm.) J. I. Cohen (monotypic)

$4^{\prime}$. Cauline leaves sessile, pedicels recurved in fruit, stems pubescent ... . . . . Andersonglossum J. I. Cohen

1'. Plants annual, biennial, or perennial; leaves relatively small, generally $<5 \mathrm{~cm}$ long; nutlets $<5 \mathrm{~mm}$ long.

5. Fruits burlike; sepals in fruit very unequal, upper $2>$ others, partly fused, arched over 1 nutlet, with 5 to 10 stout prickles, each with hooked bristles, lower 3 sepals distinct; nutlets $2 \ldots \ldots \ldots \ldots \ldots$. Harpagonella A. Gray

5'. Fruits not burlike; sepals in fruit \pm equal or, if unequal, upper $2>$ others, distinct, not arched over 1 nutlet, without prickles but with hooked or straight trichomes; nutlets 1 to 4 .

6. Mature nutlets generally 4 , widely spreading ....................... Pectocarya DC. ex Meisn. $6^{\prime}$. Mature nutlets 1 to 4 , generally erect.

7. Nutlets without ventral groove, generally with ventral ridge distal to attachment scar.

8. Corolla limbs and tubes bright yellow or orange; cotyledons 2-lobed ........ Amsinckia Lehm. p.p.

8'. Corolla limbs and tubes white to cream-colored; cotyledons not lobed.

9. Cymules glomerate; nutlet attachment scars above nutlet middle ......... Sonnea Greene

$9^{\prime}$. Cymules generally elongate (glomerate in Amsinckiopsis); nutlet attachment scars between nutlet base and nutlet middle.

10. Plant vestiture various, but not coarsely hirsute to hispid ................ $\ldots \ldots \ldots \ldots \ldots \ldots \ldots \ldots \ldots \ldots \ldots \ldots \ldots \ldots \ldots \ldots$ Plagiobothrys Fisch. \& C. A. Mey.

$10^{\prime}$. Plants coarsely hirsute to hispid.

11. Cymules more or less glomerate; corolla limbs 4-7 mm wide; nutlet abaxial

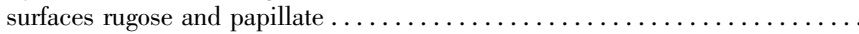
..... Amsinckiopsis kingii (S. Watson) Guilliams, Hasenstab \& B. G. Baldwin (monotypic)

$11^{\prime}$. Cymules elongate; corolla limbs 1-3 mm wide; nutlet abaxial surfaces tessellate ... ....... Simpsonanthus jonesii (A. Gray) Guilliams, Hasenstab \& B. G. Baldwin (monotypic)

$7^{\prime}$. Nutlets with ventral groove extending to apex or subapically; attachment scars generally recessed or depressed.

12. Plants annual, generally wider than tall, often rounded to cushionlike; taproots red or purple when dry (often staining herbarium paper); flower bracts present.

13. Sepals fused proximally, tubular, tube circumscissile in fruit; gynobase $<$ nutlet $\ldots . .$.

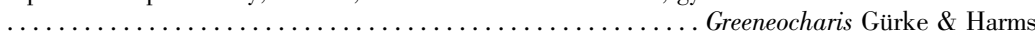

$13^{\prime}$. Sepals distinct, intact in fruit; gynobase $>$ nutlet .............. Eremocarya Greene

$12^{\prime}$. Plants annual, biennial, or perennial, generally taller than wide, rarely rounded to cushionlike; taproots usually not red or purple when dry; flower bracts absent or rarely present.

14. Plants biennial or perennial; leaves basal or tufted; nutlets smooth, rugose, or scabrous, apex broadly rounded to obtuse, ventral groove apex well below nutlet apex ..... Oreocarya Greene

14 '. Plants annual or rarely biennial or perennial; leaves generally cauline, rarely basal; nutlets smooth, papillate, tuberculate, or muricate, apex narrowly acute to acuminate, ventral groove apex almost to nutlet apex.

15. Corolla limbs bright yellow or orange; cotyledons 2-lobed ............. Amsinckia Lehm. p.p.

15'. Corolla limbs white; cotyledons not lobed (2-lobed in some South American Cryptantha).

16. Plants annual, rarely biennial (possibly perennial in Johnstonella racemosa (S. Watson ex A. Gray) Brand); flowers always chasmogamous; nutlets ovate, triangular-ovate, or lance-ovate, often heteromorphic in size and sculpturing, margin rounded or angled and then often narrowly ridged or winged, densely or sparsely tuberculate, tubercles usually whitish ........... Johnstonella Brand

16'. Plants annual; flowers chasmogamous or cleistogamous; nutlets lanceolate, lanceovate, or ovate, usually homomorphic, margin rounded or angled, not ridged or winged (except Cryptantha oxygona (A. Gray) Greene, C. cycloptera (Greene) Greene, and C. pterocarya (Torr.) Greene), smooth or papillate/tuberculate, if tuberculate, tubercles generally not whitish ....... Cryptantha Lehm. ex G. Don 
Acknowledgments. We thank Michael Simpson, Ron Kelley, Makenzie Mabry, and Lee Ripma for their collaboration on Amsinckiinae research throughout the years. We thank the editors of Novon, especially Wendy Applequist, for their assistance processing this manuscript. We thank two anonymous reviewers for their help improving the quality of this manuscript. We are grateful to the following funding sources for financial support: The American Society of Plant Taxonomists, The Annetta Carter Memorial Fund of the California Botanical Society, The California Native Plant Society, The Graduate Assembly and Graduate Division of the University of California, Berkeley, The Jiji Foundation, The Lawrence R. Heckard Endowment Fund of the Jepson Herbarium, The National Science Foundation, Northern California Botanists, The Robert Ornduff Memorial Travel Fellowship, and The University of California Institute for Mexico and the United States (UCMEXUS). We are grateful to the following entities for granting collection permits: City of San Diego, Center for Natural Lands Management, East Bay Regional Parks, United States Forest Service, and The Nature Conservancy. We thank Jose Delgadillo of Universidad Autónoma de Baja California for assistance collecting in Mexico.

\section{Literature Cited}

Cohen, J. I. 2015. Adelinia and Andersonglossum (Boraginaceae), two new genera from New World species of Cynoglossum. Syst. Bot. 40: 611-619.
Grau, J. 1983. Life form, reproductive biology and distribution of the Californian/Chilean genus Cryptantha. Pp. 231-240 in K. Kubitzki (editor), Sonderbände des Naturwissenshaftlichen Vereins in Hamburg, Vol. 7. P. Pary, Hamburg.

Greene, E. L. 1887. Some west American Asperifoliae. Pittonia 1: 8-23.

Guilliams, C. M. 2015. Diversification, Biogeography, and Classification of Amsinckiinae (Boraginaceae), with an Emphasis on the Popcornflowers (Plagiobothrys). Ph.D. Dissertation, University of California, Berkeley.

Guilliams, C. M., K. E. Hasenstab-Lehman \& R. Kelley. 2020. Plagiobothrys. In S. C. Meyers, T. Harvey, T. Jaster, K. E. Mitchell \& L. K. Hardison (editors), Flora of Oregon, Vol. 2. BRIT Press, Fort Worth (in press).

Hasenstab-Lehman, K. E. \& M. G. Simpson. 2012. Cat's eyes and popcorn flowers: Phylogenetic systematics of the genus Cryptantha s.l. (Boraginaceae). Syst. Bot. 37: 738-757.

Johnston, I. M. 1923. Studies in the Boraginaceae I. 4. A synopsis and redefinition of Plagiobothrys. Contrib. Gray Herb. 68: 57-80.

Kelley, R. B., M. G. Simpson \& K. E. Hasenstab. 2012. Cryptantha. Pp. 455-468 in B. G. Baldwin, D. H. Goldman, D. J. Keil, R. Patterson, T. J. Rosatti \& D. H. Wilken (editors), The Jepson Manual: Vascular Plants of California. ed. 2. University of California Press, Berkeley.

Simpson, M. G. 2007 onward. Systematics of Amsinckiinae (Boraginaceae): The popcorn flowers. <http://plants.sdsu.edu/ amsinckiinae $>$.

Simpson, M. G., C. M. Guilliams, K. E. Hasenstab-Lehman, M. Mabry \& L. Ripma. 2017. Phylogeny of the popcorn flowers: Use of genome skimming to evaluate monophyly and interrelationships in subtribe Amsinckiinae (Boraginaceae). Taxon 66: 1406-1420. 